\author{
초음파 유도하 관절내 주사 \\ 나경선내과 \\ 나 경 선
}

\title{
Ultrasound-guided Intra-Articular Injections
}

\author{
Kyoung-Sun $\mathrm{Na}$ \\ Dr. Na's Rheumatism Clinic, Seoul, Korea
}

Ultrasonography (US) is being used increasingly to guide diagnostic and therapeutic musculoskeletal injections. Intra-articular injection is an important mainstay in the treatment of joint diseases, including rheumatoid arthritis (RA) and osteoarthritis (OA). However, blind or palpation-based injection can result in inaccurate needle placement and can be challenging for small joints or difficult-to-access joints such as the hip joint. The correct position of the needle with guidance in the target area would improve the efficacy of the procedure and greatly improve the outcome. Compared to conventional fluoroscopic guidance, the advantages of US are that it avoids radiation exposure and the equipment is readily available and less expensive. Knowledge of anatomy and probe positioning, as well as the ability to coordinate the probe and needle are necessary when injecting patients under US guidance. This review describes the general considerations for intra-articular injections under US guidance and includes practical suggestions for the injection of individual joints. (Korean J Med 2015;89:654-662)

Keywords: Ultrasonography; Intra-Articular; Ultrasound-guided; Injection

\section{서 론}

다양한 관절, 힘줄 및 인대 질환의 진단에 있어서 근골격 계 초음파에 대한 경험과 연구가 축적되어왔다. 이에 따라 초 음파는 류마티스질환의 관리에 있어서도 필수적인 도구로 자리를 잡아가고 있다. 특히 초음파 검사를 통한 병변의 확 인과 동시에 관절내의 삼출액을 흡인하거나, 관절내 주사시 영상 유도에 활용되는 등 중재(intervention) 영역에서도 역할 이 점차 확대되고 있다[1].

관절내 주사는 류마티스관절염, 골관절염을 비롯한 여러
관절질환의 치료에 있어 중요한 부분을 차지하고 있다. 특히 부신피질호르몬 관절내 주사는 류마티스관절염의 질환 경과 를 바꾸지 못하지만, 일시적인 질병 활성도의 악화(flare)시 전신적인 부신피질호르몬을 투여하거나, 항류마티스제를 변 경하지 않고도 이를 신속하게 조절하는 효과가 있다[2,3]. 관 절 주사의 효과와 부작용은 병변 내에 바늘이 정확하게 위치 하는가에 따라 결정된다. 주사에 의한 손상은 주사 약제뿐만 아니라 바늘에 의해 직접적으로 발생할 수 있기 때문에 신 경, 힘줄, 관절 연골, 혈관 등의 구조물과 바늘의 직접적인 접촉을 피하기 위한 각별한 주의가 필요하다[4]. 이러한 관절

Correspondence to Kyoung-Sun Na, M.D., Ph.D.

Dr. Na's Rheumatism Clinic, 42 Seochojungang-ro, Seocho-gu, Seoul 06643, Korea

Tel: +82-2-585-1675, Fax: +82-2-587-1675, E-mail: naks0813@empas.com

Copyright $(2015$ The Korean Association of Internal Medicine

This is an Open Access article distributed under the terms of the Creative Commons Attribution Non-Commercial License (http://creativecommons.org/licenses/by-nc/3.0/) which permits unrestricted noncommercial use, distribution, and reproduction in any medium, provided the original work is properly cited. 
내 주사는 오래 전부터 표면해부학에 기초한 촉진을 통해 행해져 왔으나, 실제 관절내 주사의 성공률은 $50 \%$ 정도 밖 에 되지 않는다[5]. 주사의 정확성을 개선하기 위하여 투시하 검사(fluoroscopy), 컴퓨터 단층촬영, 자기공명영상 등의 다양 한 영상 장치들이 이용되고 있다. 다른 영상 검사와 비교해 초음파는 신속하고 안전하며 방사선 피폭이 없고, 상대적으 로 비용이 적어, 외래 진료 환경에서 쉽게 활용할 수 있다는 점에서 가장 실용적이라고 할 수 있다[6]. 더 중요한 점은 초 음파를 통해 투시하 검사로 볼 수 없는 신경과 혈관 등의 주 요 구조물을 확인하고 바늘의 움직임을 실시간 관찰함으로써 조영제를 사용하지 않고도 바늘을 목표하는 곳에 위치시킬 수 있다는 점이다[7].

본 종설에서는 류마티스질환의 치료로서 초음파 유도하 관절 주사를 계획할 때, 고려해야 할 기본적인 사항과 척추 를 제외한 말초관절 중에서 가장 흔하게 시술하는 관절들에 대한 실제 수기를 간략하게 기술하고자 한다.

\section{본 론}

\section{초음파 유도하 주사의 정확성과 효과}

생물학제제의 도입 등 염증성 관절질환의 전신적인 치료 에 대한 괄목할만한 발전에도 불구하고 관절, 점액낭, 건초 에 등에 대한 국소적인 스테로이드 주사는 실제 임상에서는 여전히 중요한 부분을 차지하고 있다. 이러한 주사는 대부분 영상 유도 없이 해부학적 지형물의 촉진에 의해 행해져 왔다. 그러나 촉진에 의한 비유도(blind, unguided) 주사는 바늘 위 치의 정확도가 높지 않는 것으로 알려지고 있다. 비유도관절 내 주사의 정확도를 분석한 한 연구에 의하면 어깨와 무릎 관절내 주사의 성공률은 겨우 $25 \%$ 와 $70 \%$ 에 불과했다[5]. 또 다른 연구는 어깨관절과 견봉하점액낭(subacromial bursa)에 대한 비유도 주사의 정확도를 각각 $42 \%, 29 \%$ 로 보고하였다 8$]$. 어깨, 무릎, 발목과 작은 관절에 대한 관절액 흡인의 성공률 을 비교한 연구 또한 초음파 유도의 $97 \%$ 에 비해, 비유도하는 $32 \%$ 라는 큰 차이를 보여주었다[9].

그렇다면 초음파 유도로 확보된 주사의 높은 정확도가 임 상적인 효과면에서 비유도 주사보다 우월할 것인가? 초음파 유도시 시술 관련 통증이 $43 \%$ 감소하고, 치료 반응의 비율이 $26 \%$ 증가하는 등, 초음파 유도가 시술의 성능과 효과를 의미 있게 개선하였음을 보여주는 보고가 있었다[10]. 한편, 다른 저자들은 초음파 유도하 주사의 높은 정확도에도 불구하고, 임상적인 결과면에서는 비유도 주사에 비해 의미 있는 차이
가 없었다는 보고를 통해 바늘 위치의 높은 정확성이 주사의 효과를 반드시 개선시키지는 않는다는 점을 지적하였다[11]. 비유도 주사의 부정확함에도 불구하고 유도 주사와 임상적 인 효과에서 크게 열등하지 않는 것은 부신피질호르몬이 주 변의 혈관과 구조물로의 확산되어 나타나는 국소적인 효과와 일부 전신적인 효과에 의한 것으로 설명할 수 있다[6]. 이처 럼 초음파 유도의 임상적 결과를 분석한 소수의 보고들마저 상반된 결과를 보여주고 있기 때문에, 초음파 유도와 비유도 주사 간의 단기적, 장기적 장점과 비용대비 효과를 증명하기 위해서는 더 많은 연구가 필요하다[12]. 임상적인 효과의 개 선 여부와는 별개로, 초음파 유도의 중요한 장점은 비유도하 시술시 발생할 수 있는 혈관, 신경, 및 힘줄 등의 중요한 구 조물의 손상을 피할 수 있다는 것이다[13].

\section{초음파 유도 주사의 기법}

초음파 유도 방법에는 간접법과 직접법의 두 가지의 접근 법이 있다. 간접법은 초음파로 스캔하면서 바늘이 들어갈 최 적의 위치를 선정한 후에 그 위치의 피부에 표시만 하고 실 제 바늘을 주입할 때는 초음파를 사용하지 않는 방법이다. 이 방법은 베이커낭종과 같이 피부 표면에 가까이 위치한 큰 구 조물이나 삼출액이 많은 무릎관절과 같은 큰 관절에 적합한 방법이다. 바늘이 들어갈 보다 정확한 위치를 찾기 위해서 페 이퍼 클립을 활용하기도 한다[14]. 직접법은 시술을 하는 동 안 초음파로 바늘의 위치를 실시간으로 확인하면서 바늘을 주입하는 방법이며, 촉진이 쉽지 않는 깊은 구조물을 목표로 할 때 유용하다. 이 방법은 탐촉자를 잡은 손과 바늘을 잡은 다른 손을 동시에 조화롭게 다루는 능력을 갖기 위한 연습과 경험을 요구한다.

초음파 유도시 목표물의 크기와 깊이에 따라 바늘은 탐촉 자의 장축에 평행하게 진입하거나(in-plane), 또는 직각으로 (out-of-plane) 진입할 수 있다. 바늘이 탐촉자와 평행에 가까 울수록 바늘을 더 잘 관찰할 수 있으며, 후방 반향(posterior reverberation)을 보이는 고에코의 선명한 선으로 나타난다. 한 편, 탐촉자와 바늘 사이의 각도가 가파를수록 바늘은 잘 보 이지 않게 된다(Fig. 1). 반면, 바늘이 탐촉자의 장축에 대해 직각으로 접근하게 되면, 바늘은 고에코의 하얀 점으로 관찰 된다(Fig. 2). In-plane 접근법이 대부분의 초음파 유도에 사용 되지만, 표층의 작은 관절에는 out-of-plane 접근이 보다 더 용 이할 수 있다. 바늘을 삽입한 후에 항상 종단면과 횡단면을 함께 스캔하면서 목표와 바늘 끝의 위치 관계를 확인하고 중 재술을 진행한다[15]. 

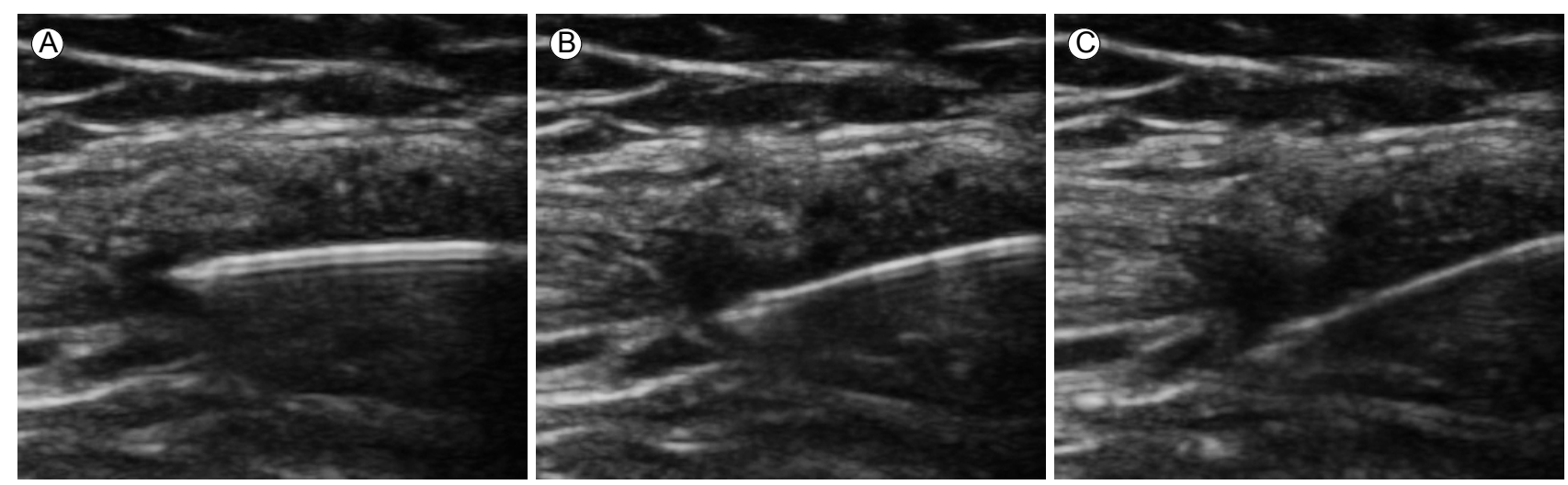

Figure 1. In-plane approach to position the needle under US guidance. (A-C) US detection of a metallic needle at different angles relative to the US beam. With increasing obliquity, the needle becomes less evident and detection of its tip is uncertain. US, ultrasound.

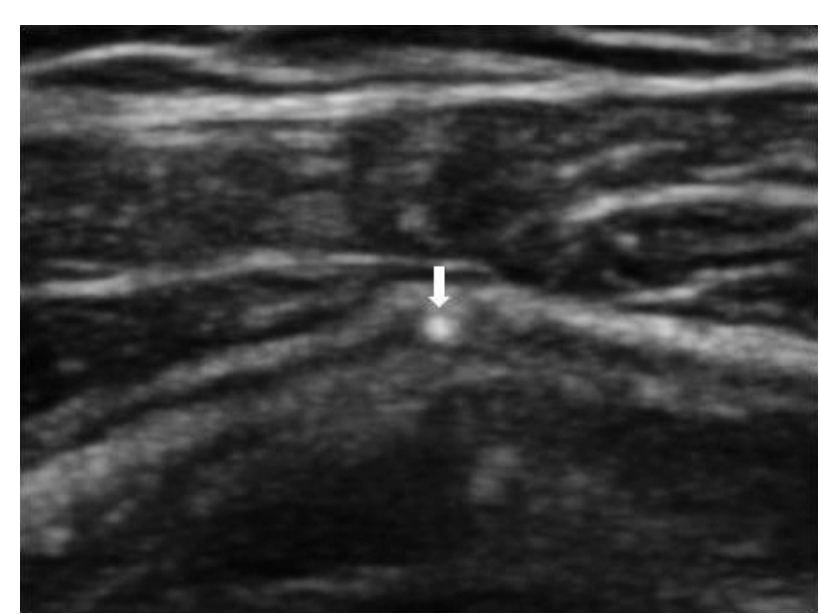

Figure 2. Out-of-plane approach for positioning a needle under US guidance. Transverse US scan of the needle shows only a hyperechoic dot (arrow). US, ultrasound.

시술 중 바늘의 시인성을 높이기 위해서는 병변의 깊이에 따라 적당한 초음파 주파수를 선택한다. 그리고 주사 바늘이 항상 초음파 빔과 수직이 되도록 노력하며 시술 중 주사침의 방향이 탐촉자 축과 정렬되어 있는지 확인하면서 시술을 시 행한다. 바늘 끝을 잘 보기 위해서는 바늘 끝 경사면(bevel)이 항상 초음파 빔 방향을 향하게 하고 바늘을 빠르게 움직이거 나 흔드는 것(jiggling)이 도움이 될 수 있다[16]. 몇몇 저자들 은 소량의 공기를 주입하는 방법을 제안하기도 했지만, 공기 는 오히려 밑에 있는 구조물을 가려 시술을 방해하는 요인이 될 수 있다[17].

\section{장비와 시술 준비}

초음파 장비는 3-5 MHz의 볼록 탐촉자와 7-15 MHz의 선 형 탐촉자가 부착되고, 도플러가 가능한 장비가 적당하다. 환
자와 시술자 모두 편안한 자세에서 시술이 진행될 수 있는 자세를 취하도록 한다[18]. 불편한 자세는 시술자의 목과 관 절의 손상을 초래할 수 있기 때문에 모니터를 추가로 연결하 여 시술자가 모니터를 정면으로 응시하는 것이 가능하도록 한다. 환자의 자세 또한 시술의 성공 여부에 상당한 영향을 주기 때문에 높낮이 조절이 가능한 전동 테이블, 베게, 수건 등을 응용하여 개별 관절에 따라 가장 적합한 자세를 취하도 록 한다.

주사 바늘의 형태와 길이는 시술하고자 하는 관절에 따라 선택한다. 일반적으로 약제의 주입은 대개 23-25 gauge의 가 는 바늘을 사용하고, 관절 천자의 경우엔 18-21 gauge의 두꺼 운 바늘을 사용한다. 바늘의 길이는 초음파 상에서 예상되는 주사 경로의 거리를 측정하여 결정할 수 있는데, 충분한 길 이의 바늘을 준비하는 것이 필요하다. 예를 들면, 어깨관절 은 적어도 $6 \mathrm{~cm}$ 이상, 고관절은 $10 \mathrm{~cm}$ 이상의 바늘을 사용하 여야 관절내에 도달할 수 있다.

초음파 유도하 주사와 관련한 소독 방법에 대한 지침이나 연구는 현재까지 없다. 시술 전 감염의 가능성을 최소화하기 위하여 시술 부위의 피부를 알코올 또는 포비돈요오드로 소 독하고 초음파 탐촉자는 멸균포로 싸고, 멸균젤을 사용할 것 을 권장한다. 그러나 멸균젤이나 멸균 탐촉자 포를 사용하지 않고 비유도하 주사와 동일한 방법으로 주사할 부위만 소독 하는 대신, 바늘과 탐촉자간의 접촉이 없도록 주의를 기울이 는 방법을 사용하는 시술자들도 있다[12].

시술 전 국소 마취는 대개 필요하지 않지만, 크고 두꺼운 관절 또는 통증에 민감한 부위나 환자일 때는 냉각 스프레이 (ethylchloride spray)나 국소 마취주사를 사용할 수 있다[18]. 


\section{개별 관절에 대한 수기}

다음에 소개하는 개별 관절에 대한 수기는 외래 진료실에 서 비교적 쉽게 활용할 수 있는 대표적인 방법들이다. 하지만 초음파 유도하 관절 주사는 항상 전통적인 경로를 따라 항상 행해지지는 것은 아니다. 목표 지점으로의 최상의 접근 방법 은 병변의 초음파적인 양상을 기초로 하여 사례별로 결정되 기도 한다[19].

\section{어깨 관절}

어깨는 근골격초음파에서 진단 및 유도하 주사의 목적으
로 가장 흔하게 초음파가 사용되는 부위이다. 관절와상완골 (glenohumeral)관절 주사는 유착성 피막염(동결견), 류마티스 관절염, 골관절염의 치료 시에 주로 행해진다. 주사 방법에 는 전방과 후방 접근법이 있으나, 초음파 유도 시엔 후방으로 접근한다. 환자는 앉은 자세 또는 옆으로 누운 자세를 취하 도록 한다. 옆으로 누운 자세가 앉은 자세보다 시술자의 어 깨와 팔에 무리가 덜 주기 때문에 이 자세가 선호된다. 환자 를 시술자를 향해 옆으로 눕히고 목표 부위의 손을 반대편 어깨 위에 올린 자세를 취하게 한 다음, 견갑골의 극돌기 아 래 극하근(infrapinatus)에 탐촉자를 위치하고 바늘을 상완 골 두의 곡면을 따라 관절와순(glenoid labrum) 바로 아래를 목
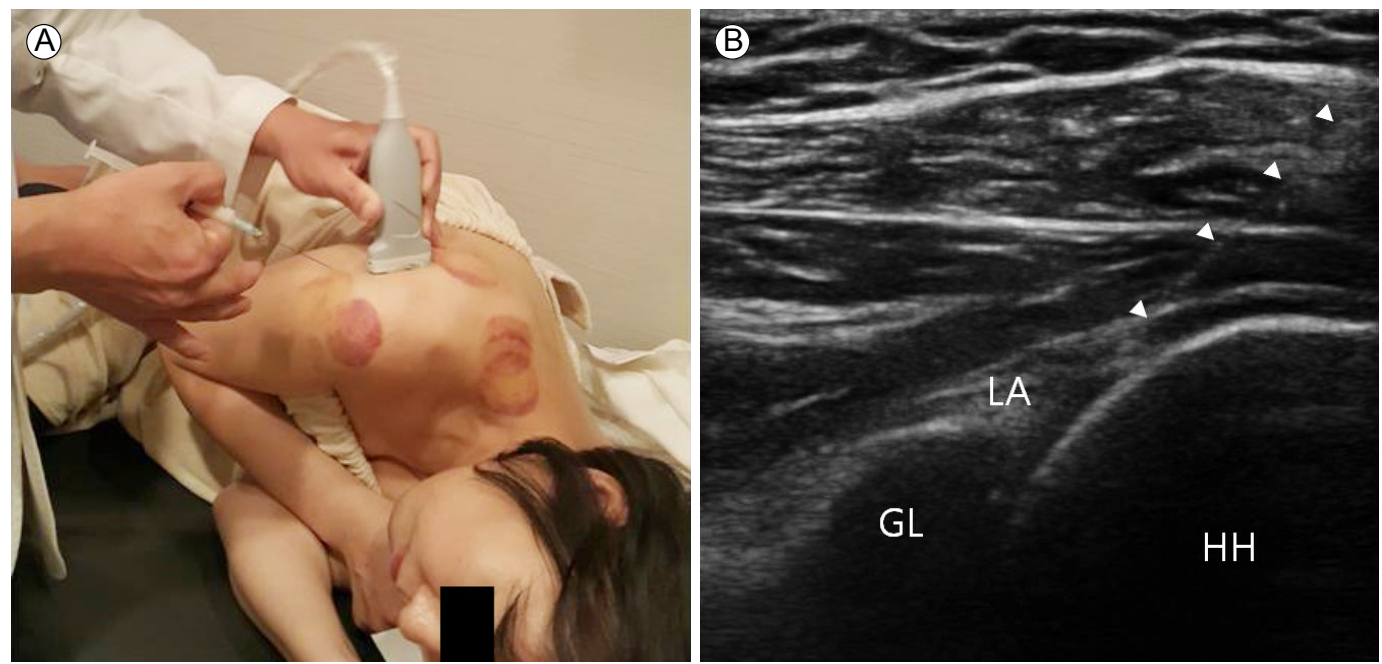

Figure 3. (A) Positioning the patient and transducer for glenohumeral joint injection. The needle is introduced via a posterior approach. (B) The needle (arrowheads) is advanced between the head of the humerus and labrum into the glenohumeral joint. LA, labrum; HH, humeral head; GL, glenoid.
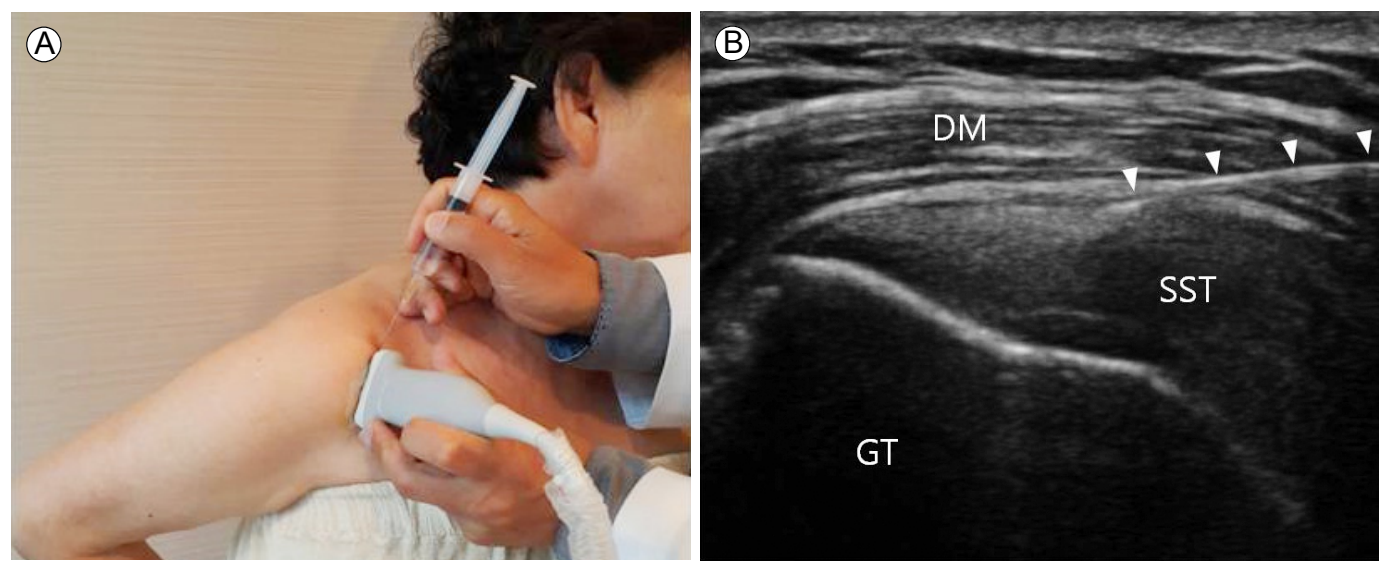

Figure 4. Superior approach to the subacromial-subdeltoid bursa. (A) The patient's arm is placed in the Crass position (elbow flexed, arm supinated, and the palm of the hand placed over the ipsilateral hip). (B) Long axis scan following the needle (arrowheads) into the subacromial-subdeltoid bursa. DM, deltoid muscle; SST, supraspinatus tendon; GT, greater tuberosity of humeral head. 
표로 하여 진입시켜 주사한다(Fig. 3) [20].

다음으로 가장 흔하게 주사하는 부위는 견봉하점액낭(subacromial bursa)이다. 회전근개건염이나 류마티스관절염에 의 한 점액낭염이 있을 때 주로 시행된다. 환자의 자세는 시술자 를 바라보고 앉게 하고 이환된 팔의 손등을 등에 붙이는 자 세(Crass 자세)를 취하게 한 다음, 극상건(supraspinatus tendon) 의 주행 방향을 따라 바늘을 위에서 아래 방향으로 삽입하고 삼각근과 극상건 사이에 있는 견봉하점액낭에 바늘을 위치 시켜 주사한다(Fig. 4).

\section{팔꿈치}

팔꿈치관절에 삼출액이 생기면 팔꿈치머리와(olecranon fossa) 의 지방체를 들어 올리기 때문에, 팔꿈치관절내 주사의 경로
는 주로 후방에서 팔꿈치머리와를 목표로 하여 접근한다. 환 자는 앉은 자세에서 팔꿈치를 굽히고 손바닥을 테이블 위에 올려놓게 한다. 초음파로 삼두근(triceps muscle), 삼두건(tricpes tendon)과 팔꿈치머리와를 장축으로 한 화면에 보이게 한 후 에 탐촉자를 시계 방향으로 돌리고 삼두건의 바깥쪽에서 팔 꿈치머리와의 지방체를 목표로 삼두근을 뚫고 주사 바늘을 삽입한다(Fig. 5) [21].

\section{손목}

손목은 류마티스관절염이 가장 흔하게 침범하는 관절 중 의 하나이다. 초음파 검사는 손목 통증과 종창의 원인이 관 절내부 또는 주변의 건초염 인지를 확인하여 목표 구조물을 결정하는데 매우 유용하다. 요골수근골(radiocarpal)관절내 주
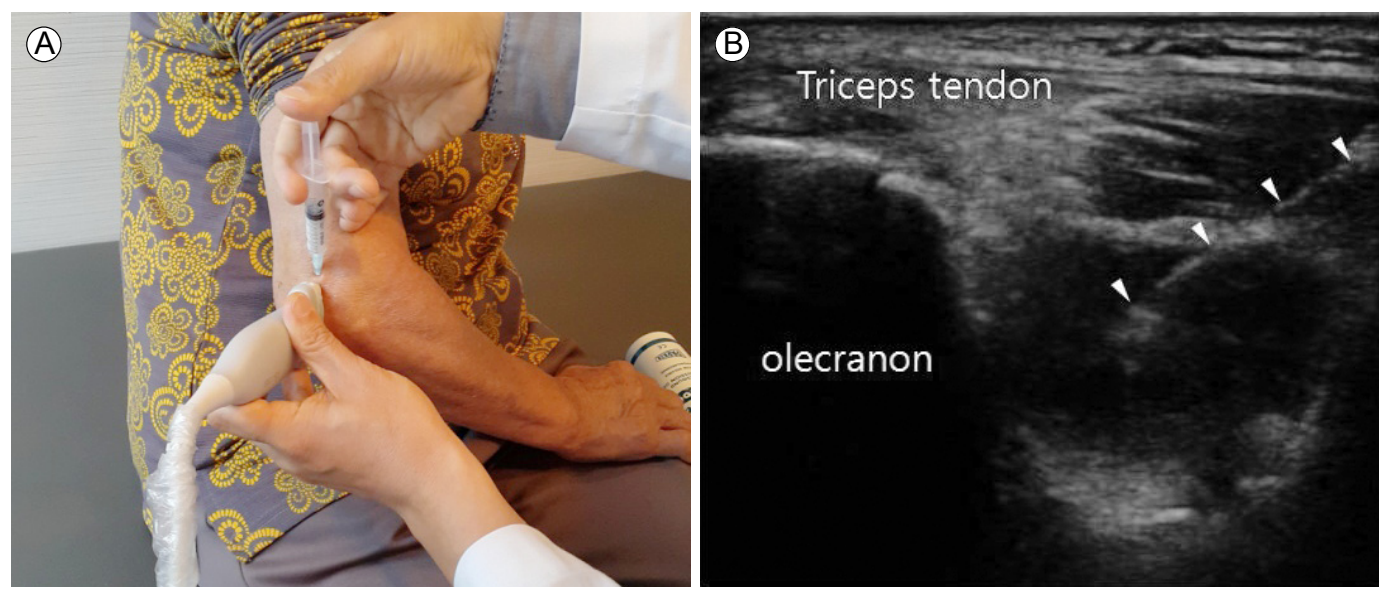

Figure 5. Patient and needle positioning for puncture of the olecranon fossa. (A) The patient is seated with the arm in retroposition and the elbow semi-flexed. The probe is aligned with the long axis of the upper arm and the triceps muscle and rotated slightly clockwise. (B) The needle (arrowheads) placement in the olecranon fossa, which is filled with an effusion and proliferated synovium.
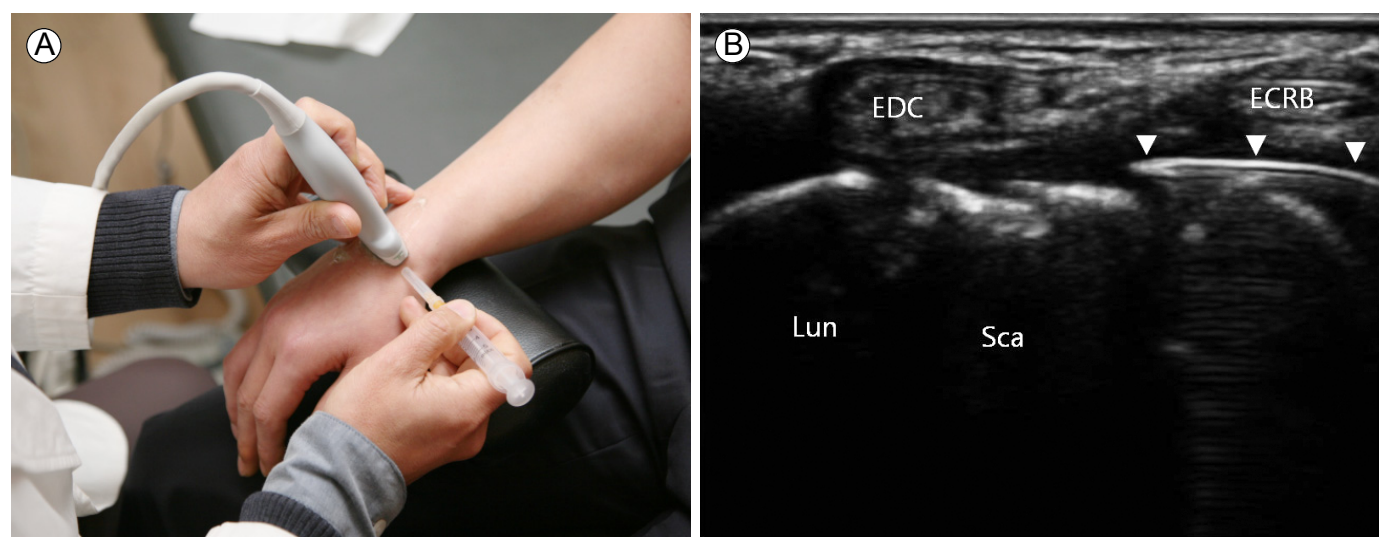

Figure 6. Radiocarpal joint injection. (A) The patient is seated with the wrist placed over a pillow. (B) The needle (arrowheads) is passed radial to extensor compartment four. EDC, extensor digitorum, compartment four; ECRB, extensor carpi radialis brevis tendon; Lun, lunate; Sca, scaphoid. 
사는 환자의 손목을 필로우에 올려두어 손목을 약간 굽힌 상 태에서 탐촉자를 종축으로 위치한 후 lister's tubercle 1-2 cm 원위부에서 바늘을 진입하는 방법이 있으며, 탐촉자를 손목 에 횡축으로 위치한 후 요골방향에서 요골수근골 관절면에 평행하게 $2^{\text {nd }}$ extensor tendon compartment 아래로 통해 바늘을 진입시켜 주사하기도 한다(Fig. 6) [22].

손목터널증후군 환자에서 초음파 검사상 손목터널의 근위 부의 정중신경이 저에코로 두꺼워져 있는 변화를 발견할 수 있다[23]. 탐촉자를 손목터널에 횡축으로 놓고 손목터널의 근 위부에서 바늘을 삽입하여 정중신경과 횡수골인대(transverse carpal ligament)의 사이 또는 정중신경의 요골 측면 또는 척 골 측면을 목표로 약제를 주입한다(Fig. 7). 초음파 유도는 주 사로 인한 정중신경과 척골, 요골 동맥의 손상을 피하는 데 도움을 준다.

\section{고관절}

고관절은 다른 관절에 비해 깊은 곳에 위치하고 주변에 대 퇴 동맥, 정맥 및 신경이 있어, 촉진을 통한 비유도 주사가 거 의 불가능하다. 이 때문에 이 부위에 대한 시술시 초음파 유 도가 필수적이라고 할 수 있다. 고관절의 공간은 비구(acetab-
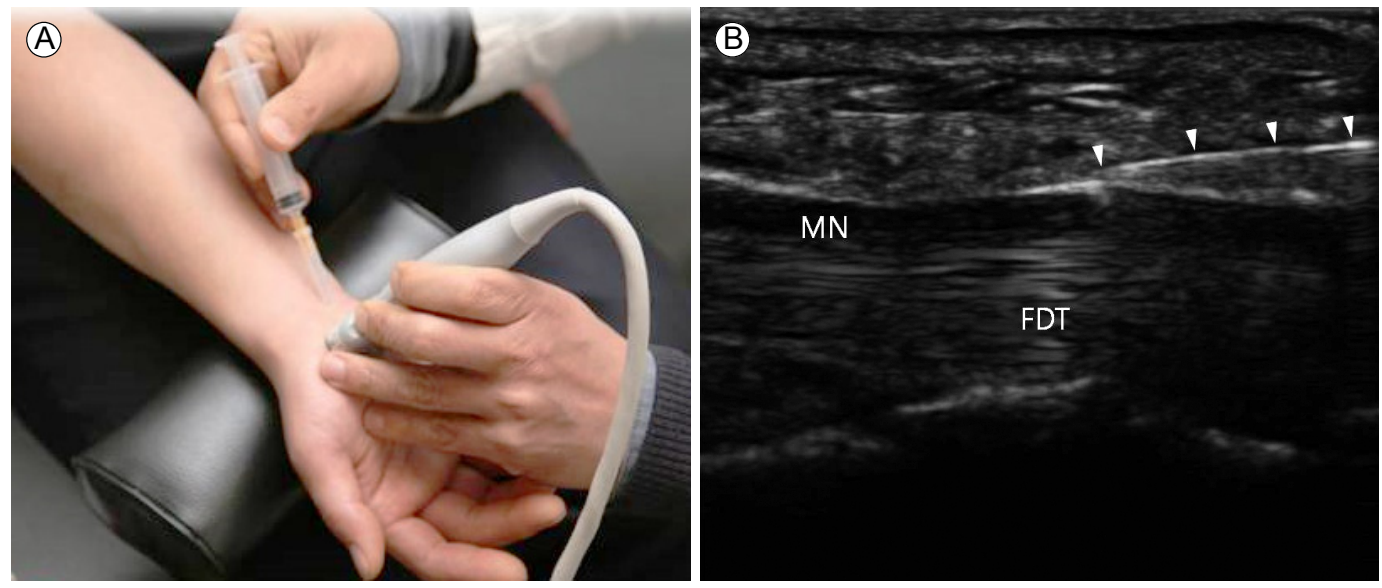

Figure 7. Carpal tunnel injection. (A) The patient is seated with the forearm extended on a pillow in the supinated position. (B) The needle (arrowheads) is inserted between the transverse carpal ligament and median nerve. MN, median nerve; FDT, flexor digitorum tendons.
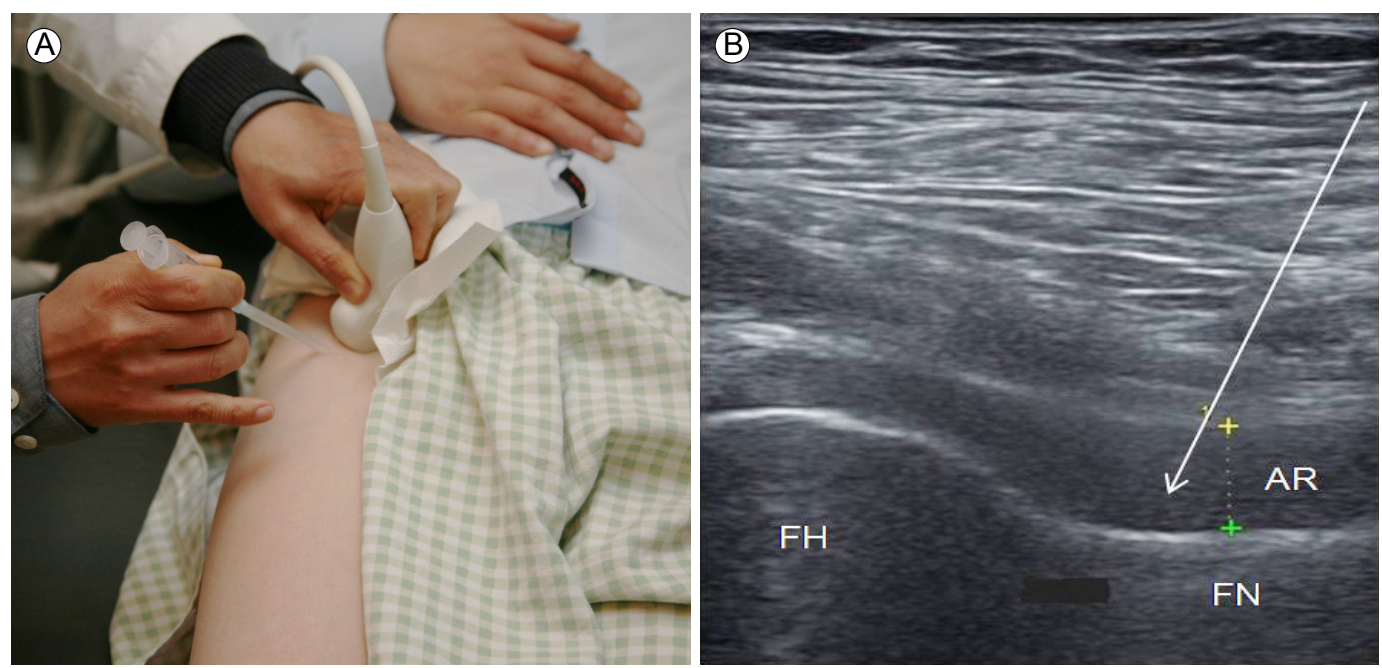

Figure 8. Hip joint injection. (A) Anterior longitudinal approach to the hip joint. In the supine position, the transducer is aligned parallel to the neck of the femur. (B) The needle (arrow) is targeted to the anterior synovial recess located at the neck of the femur. FH, femoral head; AR, anterior recess of hip joint; FN, femoral neck. 

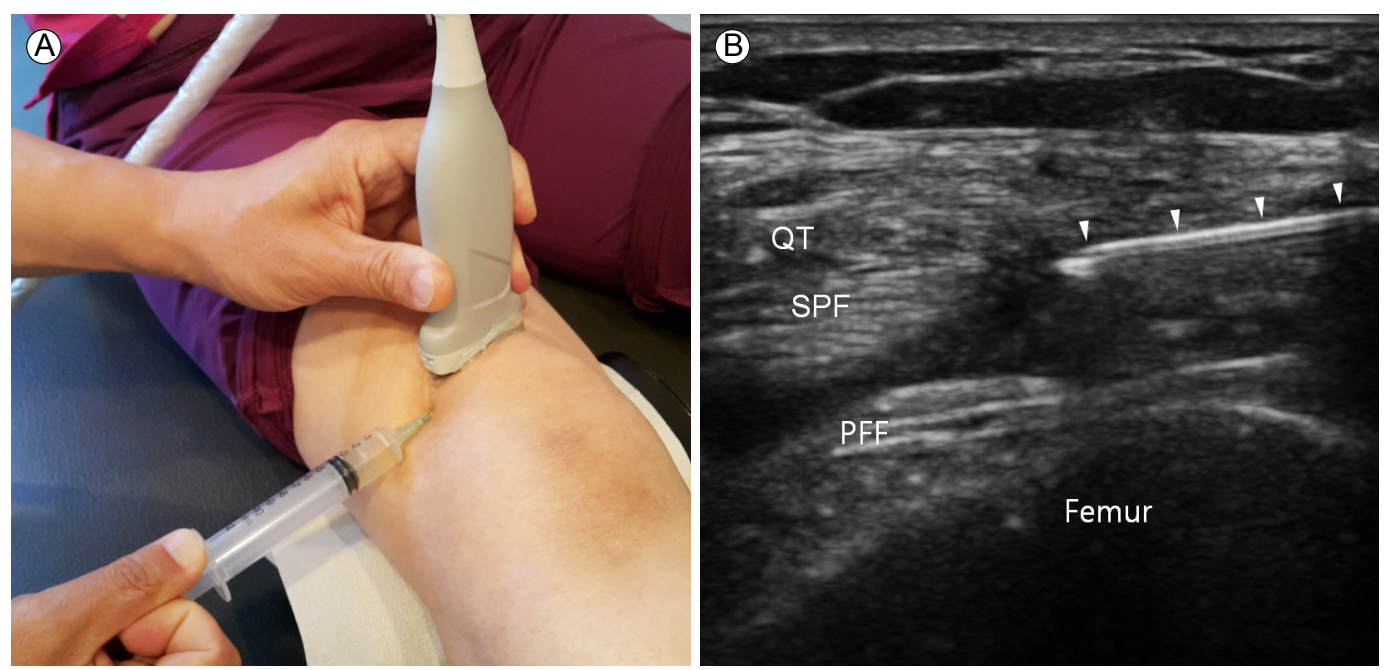

Figure 9. Knee joint injection. (A) The patient is supine with the knee semiflexed over a pillow. (B) Transverse suprapatellar anterior scan of the knee. The needle (arrowheads) is introduced through the superolateral portal of the knee into the suprapatellar recess. QT, quadriceps femoris tendons; SPF, suprapatellar fat pad; PFF, prefemoral fat pad.

ulum)와 순(labrum)에 의해 막혀있는 형태이기 때문에 바늘 의 위치는 대퇴 골두와 경부의 전방에 위치한 전방와(anterior recess)를 목표로 한다. 환자는 반듯이 누운 상태에서 고관절 을 중립 위치를 두게 한다. 탐촉자를 내측으로 20도 기울여 고관절을 종축으로 스캔을 하면서, 내측에 있는 대퇴혈관과 신경을 확인하고 탐촉자를 대퇴 경부에 평행이 되도록 위치 시킨다. 바늘은 탐촉자의 원위부에서 45 도 각도로 진입하며, 대퇴 골두의 바로 아래에 위치한 전방와 내로 전진시킨다 (Fig. 8) [14].

\section{무릎}

무릎관절내 주사는 일반적으로 영상 유도 없이 높은 정확 도로 쉽게 시술되는데, 환자가 비만하거나 삼출액의 양이 매 우 적은 경우, 초음파 유도가 도움이 많이 된다[17]. 또한 고 분자량의 히알루론산 관절내 주사는 관절외 연부 조직 내로 주사된 경우 심한 통증을 유발할 수 있어 초음파 유도하 주 사가 권장되기도 한다[24]. 환자의 자세는 슬와에 필로우를 넣어 무릎을 2-30도 굽힌 상태에서 슬개골의 외측에서 바늘 을 진입시킨다(Fig. 9).

베이커낭종의 흡인과 스테로이드 주사를 할 때도 초음파 는 유용하다. 슬와에 혹이 만져지는 경우, 베이커낭종 이외에 도 슬와동맥류, 반월상연골낭종(meniscal cyst) 또는 정맥염이 원인인 경우도 있기 때문에, 천자를 하기 전에 초음파로 감별 진단을 하는 것이 안전하다. 낭종 내부에 활액막의 비후, 출 혈, 석회, 유리체 등을 포함하고 있거나 낭종이 파열된 복잡

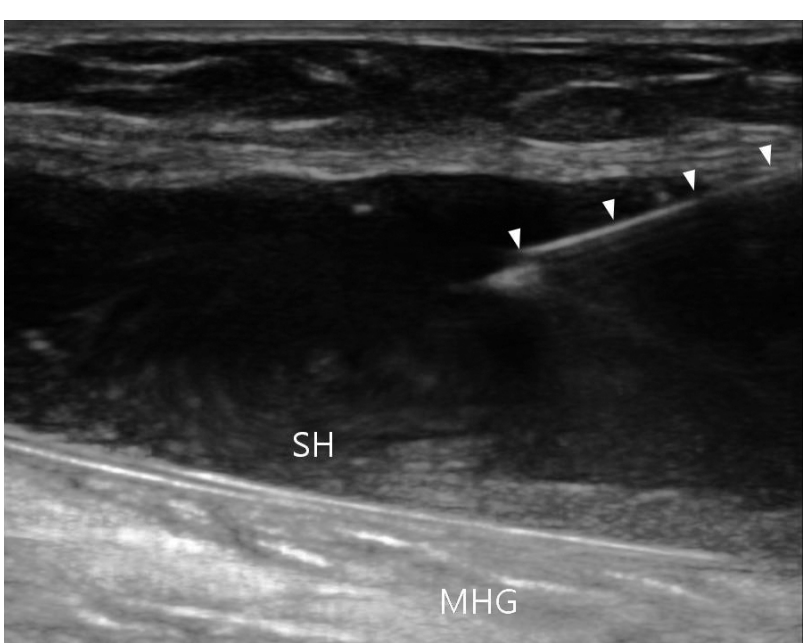

Figure 10. US-guided aspiration of a complicated Baker's cyst. The needle (arrowheads) is advanced into the center of the cyst, which is filled with an effusion and proliferated synovium. US, ultrasound; SH, synovial hypertrophy; MHG, medial head of gastrocnemius muscle.

한 경우에는 초음파 유도 없이 성공적인 흡인이 어려울 수 있다[25]. 환자를 엎드리게 한 후 슬와의 안쪽에 종축으로 탐 촉자를 위치시키고 원위부에서 바늘을 진입시켜 바늘이 낭 종 안에 들어가 있는 것을 확인 후 흡인한다(Fig. 10).

\section{발목과 발}

정강목말(tibiotalar)관절의 주사는 탐촉자를 관절 위에 횡 축으로 두고, 내측 또는 외측에서 바늘을 진입시켜 정강목발 

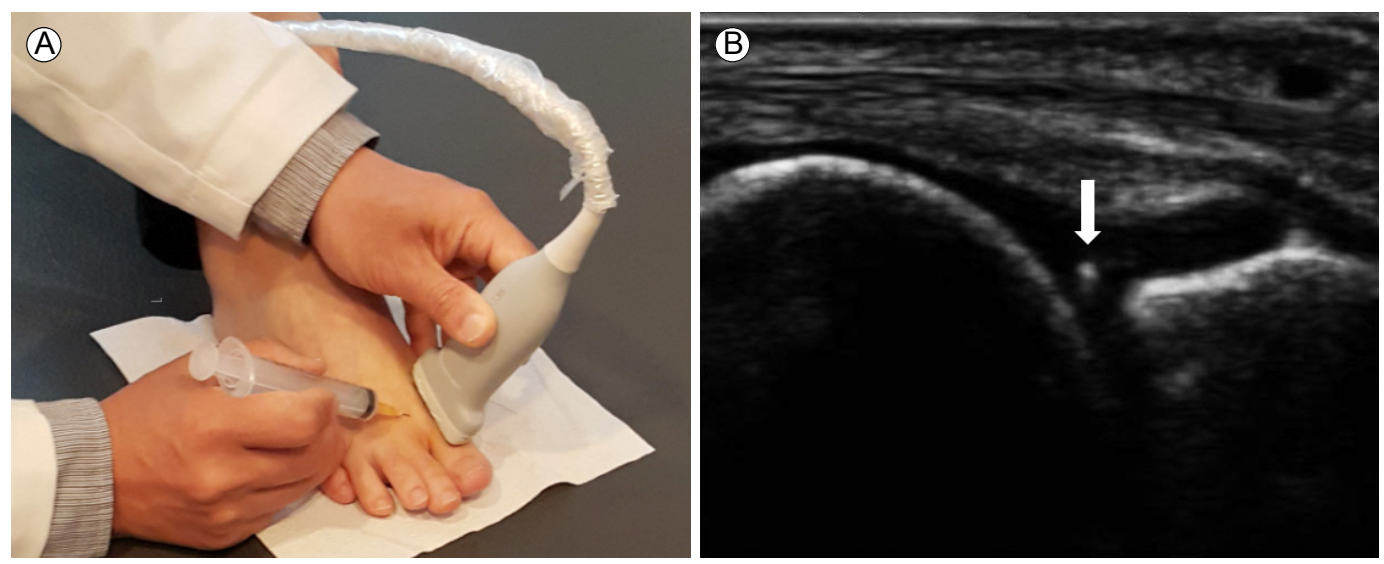

Figure 11. (A) Position of the patient for a metatarsophalangeal (MTP) joint injection. The needle is introduced from the medial side, perpendicular to the probe. (B) Longitudinal dorsal scan of the first MTP joint shows the needle as a hyperechoic spot in the effusion (arrow). MTP, metatarsophalangeal joint.

관절의 원위부 배측와(distal dorsal recess) 안에 위치시킨다. 또 다른 방법은 탐촉자를 종축으로 두고 발등동맥과 장족지신 근(extensor digitorum longus)을 확인하고 이들 구조물을 피해 원위부에서 바늘을 진입시키는 것이다. 거주상골(talonavicular) 관절, 설주상골(cueonavicular)관절, 리스프랑관절 등도 유사한 방법으로 주사한다. 이들 관절들은 바로 피부 아래에 위치하 기 때문에, 탐촉자를 관절의 종축으로 두고, 바늘을 탐촉자에 직각으로 진입하는 방법(out of plane)이 더 용이할 수 있다.

중족지(metatarsophalangeal)관절과 같이 작고 표재성인 관 절은 in-plane 접근이 사실상 어렵기 때문에 out of plane 접근 법으로 탐촉자의 중심에서 직각으로 바늘을 진입시켜 주사 한다(Fig. 11). 중족지관절의 삼출액을 흡인하여 편광현미경 검사를 하고자 할 때, 초음파 유도가 매우 유용하며, 삼출액 의 양이 많지 않은 경우엔 초음파 유도 하에 생리식염수를 관절내에 주입한 후 검체를 얻을 수도 있다.

\section{결 론}

초음파 유도는 관절 주사의 정확성을 높이고, 혈관, 신경 등의 주요 구조물의 손상을 피할 수 있는 장점을 지니며, 외 래 진료실에서 쉽게 적용할 수 있는 편의성을 가지는 유용한 도구이다. 그러나 현재까지 관절 주사시 초음파 유도는 제한 적으로 사용되고 있으며, 적응증과 수기에 대한 표준화된 지 침이 없는 실정이다. 근골격계 초음파가 관절질환을 다루는 임상 의사라면 반드시 숙지해야 할 필수 검사로 자리 잡아 가고 있는 만큼 초음파 유도하 주사에 대한 많은 연구와 함 께, 다양한 교육 과정이 마련되어야 할 것이다.
중심 단어: 초음파; 관절내; 초음파 유도하; 주사

\section{REFERENCES}

1. Koski JM. Ultrasound guided injections in rheumatology. J Rheumatol 2000;27:2131-2138.

2. Weiss MM. Corticosteroids in rheumatoid arthritis. Semin Arthritis Rheum 1989;19:9-21.

3. Furtado RN, Oliveira LM, Natour J. Polyarticular corticosteroid injection versus systemic administration in treatment of rheumatoid arthritis patients: a randomized controlled study. J Rheumatol 2005;32:1691-1698.

4. Kumar N, Newman RJ. Complications of intra- and peri-articular steroid injections. Br J Gen Pract 1999;49:465-466.

5. Jones A, Regan M, Ledingham J, Pattrick M, Manhire A, Doherty M. Importance of placement of intra-articular steroid injections. BMJ 1993;307:1329-1330.

6. Iagnocco A, Naredo E. Ultrasound-guided corticosteroid injection in rheumatology: accuracy or efficacy? Rheumatology (Oxford) 2010;49:1427-1428.

7. Epis O, Iagnocco A, Meenagh G, et al. Ultrasound imaging for the rheumatologist. XVI. Ultrasound-guided procedures. Clin Exp Rheumatol 2008;26:515-518.

8. Eustace JA, Brophy DP, Gibney RP, Bresnihan B, FitzGerald O. Comparison of the accuracy of steroid placement with clinical outcome in patients with shoulder symptoms. Ann Rheum Dis 1997;56:59-63.

9. Balint PV, Kane D, Hunter J, McInnes IB, Field M, Sturrock RD. Ultrasound guided versus conventional joint and soft tissue fluid aspiration in rheumatology practice: a pilot study. J Rheumatol 2002;29:2209-2213.

10. Sibbitt WL Jr, Peisajovich A, Michael AA, et al. Does sonographic needle guidance affect the clinical outcome of intra- 
articular injections? J Rheumatol 2009;36:1892-1902.

11. Cunnington J, Marshall N, Hide G, et al. A randomized, double-blind, controlled study of ultrasound-guided corticosteroid injection into the joint of patients with inflammatory arthritis. Arthritis Rheum 2010;62:1862-1869.

12. Koski JM, Hammer HB. Ultrasound-guided procedures: techniques and usefulness in controlling inflammation and disease progression. Rheumatology (Oxford) 2012;51 Suppl 7: vii31-vii35.

13. Sofka CM, Collins AJ, Adler RS. Use of ultrasonographic guidance in interventional musculoskeletal procedures: a review from a single institution. J Ultrasound Med 2001;20: 21-26.

14. D'Agostino MA, Schmidt WA. Ultrasound-guided injections in rheumatology: actual knowledge on efficacy and procedures. Best Pract Res Clin Rheumatol 2013;27:283-294.

15. McNally E. Practical musculoskeletal ultrasound. 2nd ed. London: Churchill Livingstone, 2014.

16. Koh YW. Ultrasound-guided intervention in musculoskeletal system. J Korean Soc Ultrasound Med 2005;24:157-167.

17. Cardinal E, Chhem RK, Beauregard CG. Ultrasound-guided interventional procedures in the musculoskeletal system. Radiol Clin North Am 1998;36:597-604.

18. De Zordo T, Mur E, Bellmann-Weiler R, et al. US guided in- jections in arthritis. Eur J Radiol 2009;71:197-203.

19. Grassi W, Farina A, Filippucci E, Cervini C. Sonographically guided procedures in rheumatology. Semin Arthritis Rheum 2001;30:347-353.

20. Zwar RB, Read JW, Noakes JB. Sonographically guided glenohumeral joint injection. AJR Am J Roentgenol 2004;183: 48-50.

21. Bruyn GA, Schmidt WA. How to perform ultrasound-guided injections. Best Pract Res Clin Rheumatol 2009;23:269-279.

22. Lohman M, Vasenius J, Nieminen O. Ultrasound guidance for puncture and injection in the radiocarpal joint. Acta Radiol 2007;48:744-747.

23. Tai TW, Wu CY, Su FC, Chern TC, Jou IM. Ultrasonography for diagnosing carpal tunnel syndrome: a meta-analysis of diagnostic test accuracy. Ultrasound Med Biol 2012;38: 1121-1128.

24. Lussier A, Cividino AA, McFarlane CA, Olszynski WP, Potashner WJ, De Médicis R. Viscosupplementation with hylan for the treatment of osteoarthritis: findings from clinical practice in Canada. J Rheumatol 1996;23:1579-1585.

25. Chen CK, Lew HL, Liao RI. Ultrasound-guided diagnosis and aspiration of Baker's cyst. Am J Phys Med Rehabil 2012; 91:1002-1004. 